\title{
Language and Literature Education in Azerbaijan and Turkey
}

\author{
Ayşe Derya Eskimen \\ Correspondence: Kütahya Dumlupınar University, Faculty of Education, Department of Turkish and Social Sciences \\ Education, Ankara, Turkey.
}

Received: August 5, 2018

Accepted: September 2, 2018

Online Published: September 6, 2018

doi:10.11114/jets.v6i11.3606

URL: https://doi.org/10.11114/jets.v6i11.3606

\begin{abstract}
Turkish world geography is a vast geography. In its broadest sense, it expands from Balkans in the west to the Pacific Ocean in the east; from the Arctic Ocean in the North to Tibet in the South. The subject of our study is Azerbaijan which is one of the independent states in this geography. In the study, similarities and differences of Turkish and Azerbaijan education system, language-literature education, curriculum, course books were analysed. Azerbaijan was chosen for the study since it is akin to Turkey in the sense of language and geography and it also takes the head in Turkish world in education and culture. In the collection of data, document review method was used and in the light of information acquired, positive aspects of both countries were used.
\end{abstract}

Keywords: language and literature textbooks in turkey and Azerbaijan, language and literature curriculum, material analysis

\section{Introduction}

Presently Turkic nations are settled in a widely expansive area approximately spanning over Balkans in the western direction, Pacific Ocean in the eastern direction, Arctic Ocean in the northern direction and Tibet in the southern direction (Turkish-World Companion, 2001, p. 6). Within the territory of these wide borders, seven Turkish nationalities exist as independent states; Turkey, Turkish Republic of Northern Cyprus, Azerbaijan, Turkmenistan, Uzbekistan, Kyrgyzstan and Kazakhstan (Topal et al. 2016, p. 97). One of these independent states, Azerbaijan Turks, have decidedly taken the lead in the domains of education and culture in Turkish world (Gömeç, 2001, p. 731). After the transition to independence in 1991 a number of changes, innovations and modernizations were ignited in education system that observed national and moral values. The onset of this new era started to be clear with the implementation of planned and approved Education Act. In the new Constitution $42^{\text {nd }}$ item clearly stipulated the right of education for all citizens (Azerbaijan Respublikası. Konstitutsiyas1, 2006, p. 15 quot. Mammadov, 2008). Official language of Azerbaijan Republic is Azerbaijan language. In Azerbaijan Republic schools official language of education is Azerbaijan language by virtue of being the language of Azerbaijan state. In the Azerbaijan Republic's Constitution (45 ${ }^{\text {th }}$ item) it is promulgated that, for all Azerbaijan citizens, it is a constitutional right to receive education in the language they want to be engaged in creativity tasks and in conducting scientific researches. In Azerbaijan the right of speaking one's mother language is a citizenship right that cannot be denied from any given individual. Nonetheless, while providing education in the language of foreigners and minorities, it is mandatory to observe national standards and to teach Azerbaijan Language and Literature, Azerbaijan History and Azerbaijan Geography courses in tandem (Agamaliyev, 1999; Mammadov, 2008, p. 26). Prior to independence, Azerbaijani Turkish as a language was taught in two levels of public education namely in elementary and secondary education levels; yet Azerbaijani Turkish was excluded in high school curriculum. Azerbaijani Turkish was integrated into the curriculums of $9^{\text {th }}$ and $10^{\text {th }}$ graders in 1993-1994 academic year for the very first time. Subsequent to independence, educational reformation in Azerbaijan allowed some modernization in the literature curriculums of secondary education level as well. In that sense literature curriculum concocted in 2003 to replace literature curriculum of year 1994 can be regarded as an evidence of the modernization process; new curriculum was designed in the new Azerbaijani Turkish language, promulgated across Azerbaijan schools and textbooks were prepared in line with the new curriculum shortly after (Celilova, 2012, p. 201). As we investigate Turkey dimension of their reform it can be observed that in Turkish Language and Literature course a range of amendments and reforms have taken place particularly after 2005 to redesign both the curriculum and textbooks by trying unprecedented approaches. Before issuing 2018-dated curriculum, Turkish Language and Literature course has been bifurcated as Turkish Literature, Language \& Language and Discourse course as of year 2005. Reportedly they were mainly geared at structuring of knowledge. By uniting the two components in one unit the first attempts of 
designing a draft for Turkish Language and Literature curriculum were initiated in 2015. Subsequent to curriculum-development works, by issuing 19/01/2018 dated no. 39 Act it was officially resolved to teach Secondary-Education level Turkish Language and Literature Course $\left(9^{\text {th }}, 10^{\text {th }}, 11^{\text {th }}\right.$ and $12^{\text {th }}$ grades $)$ curriculum in all grade levels starting with 2018-2019 academic year (http://mufredat.meb.gov.tr/ProgramDetay.aspx?PID=353). Accordingly, it was agreed that with the implementation of Secondary-Education level Turkish Language and Literature Course $\left(9^{\text {th }}, 10^{\text {th }}, 11^{\text {th }}\right.$ and $12^{\text {th }}$ grades $)$ effectuated with $17 / 07 / 2017$ dated no. 67 Act and Secondary-Education level Turkish Language and Literature Course $\left(9^{\text {th }}, 10^{\text {th }}, 11^{\text {th }}\right.$ and $12^{\text {th }}$ grades) effectuated with $29 / 07 / 2015$ dated no. 63 Act; the former curriculum would no longer be implemented in any grade levels as of 2018-2019 academic year.

Based on the fact that all the components above are linked with public education system, public education systems and educational approaches of the two states have been comparatively analyzed in this study. Thus it is the objective of this study to draw a comparative analysis between the language and literature teaching practices of Turkey and Azerbaijan in secondary education level. The best way to protect one's mother language is to help native speakers appreciate the vitality of their native language. In the light of all these findings it is safe to attest that language is the key material of literature. Born out of language literature is quite important as the bearer of a culture. It is thus essential to grasp the vitality of teaching and education domains. Indeed as also reported by Erden (1998, p. 180); "Success ratio of students in higher education institutes heavily relies on the quality of education offered in secondary education institutes. Within that context the scope of this research entails language \& literature curriculum and textbooks studied in secondary education level. In the secondary education level of both countries, language and literature curriculums and textbooks have been examined respectively.

\section{Method}

Since our study described an already-existing condition via harnessing document analysis, it can be categorized as a descriptive study having employed analysis techniques for descriptive data. In data collection document analysis has been the selected method. Research document consists of literature teaching curriculum of $10^{\text {th }}$ and $11^{\text {th }}$ grades and books in Azerbaijan education system as well as $9^{\text {th }}-12^{\text {th }}$ grade curriculum of Turkish Language and Literature and $10^{\text {th }}$ grade textbooks prepared in accordance with this curriculum. Collected data have been evaluated by following these steps; "five stages of document analysis were respectively implemented (1) accessing the documents, (2) verifying the originality, (3) understanding the documents, (4) analyzing the data and (5) utilizing the data" (Forster 1995 quot. Yıldırım and Şimşek 2008, p. 193). Next, identified similarities and differences in the curriculums and textbooks of both countries were tabulated.

\subsection{Limitations of the Study}

In Azerbaijan case, high-school education curriculum and also textbooks prepared in accordance with their curriculum were limited with $10^{\text {th }}$ and $11^{\text {th }}$ grades only. As for Turkey, textbooks that are prepared in line with the revised Turkish Language and Literature teaching curriculum entail $9^{\text {th }}$ and $10^{\text {th }}$ grades. Thus, in order to ensure equality on the sides of two countries, $10^{\text {th }}$ grade language and literature textbooks alone have been elaborated to conduct a comparative analysis between Turkey and Azerbaijan.

\section{Findings}

\section{a. Education System of Turkey and Azerbaijan \& Respective Educational Objectives}

To clarify the public education systems of the two countries constituting the scope of this research, interpretations have specifically focused on language and literature. In relation to that motive, the table below illustrates that education systems and objectives of both countries possess a number of similarities as well as a few differences. In the education systems of Azerbaijan and Turkey; authority and responsibility is concentrated in one center. It is detected that objectives of Turkish education system are geared at raising nation-scale individuals rather than raising citizens to enter the global competition. Objectives of Azerbaijan education system on the other hand emphasize raising the type of people able to rapidly integrate into the world, respectful to his/her homeland, fellow citizens, rights of other citizens, and imbued with ambition to place his/her homeland, Azerbaijan, into the global list of developing countries. In Azerbaijan, compulsory education spans over 11 years but in Turkey it lasts 12 years; high-school education in Turkey continues for 4 years $\left(9^{\text {th }}-12^{\text {th }}\right.$ grades $)$ but in Azerbaijan secondary education lasts 2 years $\left(10^{\text {th }}-11^{\text {th }}\right.$ grades $)$. Both in Azerbaijan and in Turkey, after completing secondary education students are eligible to continue higher education. In Azerbaijan each academic year lasts 4 semesters while in Turkey it lasts 2 semesters. In Turkey an academic year continues for 180 days and in Azerbaijan it lasts for 36 weeks. 
Table 1. Public education systems in Turkey and Azerbaijan \& educational objectives

\begin{tabular}{ll}
\hline \multicolumn{1}{c}{ Turkey } & \multicolumn{1}{c}{ Azerbaijan } \\
\hline $\begin{array}{l}\text { In secondary education high-school covers } 9^{\text {th }}-12^{\text {th }} \\
\text { grades. Its length is } 4 \text { years. }\end{array}$ & $\begin{array}{l}\text { High-schools cover } 10^{\text {th }}-11^{\text {th }} \text { grades. Its length is } 2 \\
\text { years. }\end{array}$ \\
Secondary education lasts 8 years. & Secondary education lasts 11 years. \\
Elementary school lasts 4, secondary school lasts 4 & Elementary school lasts 4 , secondary school lasts 7 \\
and high-school lasts 4 years. & years. \\
Compulsory education lasts 12 years. & First 9 years of education are compulsory; last 2 years \\
& are optional. \\
An academic year has 2 semesters. & An academic year has 4 semesters. \\
An academic year lasts $(90+90) 180$ days. & An academic year lasts 36 weeks. \\
An academic year has 2 holidays. & An academic year has 3 holidays. \\
\hline
\end{tabular}

Source: Tabulated data above on Azerbaijan is based on the findings collected from studies of Aladdinov, 2006, $\mathrm{p}$. 56-60-62; Sadigov, 2009, p. 11-13; Nesirov, 2007, p. 86; Celilova, 2012.

General objectives of education in Turkey;

1. To raise citizens devoted to Ataturk reforms and principles and Ataturk nationalism as stipulated in the Constitution of Turkey; to internalize, advocate for and develop the national, moral, human, ethical and cultural values of the Turkish nation; to love one's family, homeland, and fellow citizens and always to strive to exalt these entities; to be aware of the duties and responsibilities towards the Turkish Republic which is a democratic, laic and social state of laws respecting human rights and established on the basic tenets listed in the introduction of the Constitution and to raise citizens who have transformed these acknowledgments into behaviors; 2 . to raise productive, creative and efficient citizens who have balanced mental, moral, spiritual, physical and emotional health and who have a strong personality and character that encompasses a free and scientific way of thinking and an expanding worldview with full respect to all human beings and who value individuality and enterprise and bear a sense of responsibility towards society; 3 . To improve citizens' interests, competencies, and skills and to adopt the essential knowledge, skills and behaviors as well as a cooperative work ethic that will prepare them for life and help them to attain a profession that gives personal satisfaction and contributes to societal wellbeing thereby; increasing the welfare and joy of Turkish citizens and Turkish society; and to support and boost financial, social and cultural development in national unity and harmony thereby making the Turkish Nation one of the most productive, creative and distinguished participants in modern civilization at large (MEB-Ministry of National Education- Fundamental Law, 1973).

General objectives of education Azerbaijan;

To raise multidimensional, extensive, having solid knowledge, skilled, competent in his/her specific field, cultured, attached to his/her own past and generation, national and moral values, loyal to national independence and democratic tenets, quick in integrating to developing world, loving his/her homeland and nation, respectful to citizens' rights and ambitious to place his/her homeland, Azerbaijan, into the list of developing countries of the world. To put this differently; the highest goal of education system of Azerbaijan is to raise Azerbaijani youth who could immortalize and internalize national independence (Education Act., 199, p. 9 quot. Mammadov, 2008).

\section{b. High-School Level Language-Literature Teaching Curriculums of Turkey and Azerbaijan}

Overall it is feasible to list four stages of language and literature education provided in high-schools. These stages are; school curriculum the lead actors of which are students, textbook and course teacher. In the Dictionary of Educational Terminology (1974) education is defined such; "The act of teaching the requirements towards a specific objective; providing information to a group of students in an education institute on a particular topic or topics". Education can be actualized in schools by implementing specific curriculums, a course book designed according to the curriculum and arranging teaching and learning process as approved. Specific objectives of 2018-issued teaching curriculum of Turkish Language and Literature course $\left(9^{\text {th }}-12^{\text {th }}\right)$ are to help students grasp literature's function and its significance in both personal and societal level; to help students realize subtleties of Turkish language, the transformation and development Turkish literature exhibited in the process of history, to internalize national, moral, ethical, cultural and universal values by referring to literary texts as a medium. As for Azerbaijan language and literature; curriculums for grades $10^{\text {th }}-11^{\text {th }}$ were devised to achieve the tasks listed here in after: a) To develop a basic comprehension level on the nature and rules of rhetoric; b) To inoculate differences and similarities across a range of literary eras; c) To gain an appreciation for the role of Azerbaijan literature in developing national values and its important position globally; to help students see the urgency to know phonetic, lexical, grammatical advantages of Azerbaijan Language from which they are required to gain benefits by using the language appropriately, timely and suitably; to forge an awareness of the subtleties of their native language among students and develop a unique literary taste; to hone their skills with the aim of appreciating the beauties of words and thoughts (Aladdinov, 2006, p. 56-60-62; Sadigov, 2009, p. 11-13,18; Celilova, 2012, p. 264; 
introduction part of the Azerbaijan Language textbook for $10^{\text {th }}$ grade; MEB 2018, p. 12; Abbasov, 1998, p. 52 quot. Celilova; Ümumtehsil Mekteblerinin V-XI. Sınıfları Üçün Edebiyyat Müfredatı, 2003, p. 3-6; Celilova, 2012, p. 282).

In Turkey, Turkish Language and Literature course has 5 hours of teaching in a week and the course is grouped under three main headings as "Reading", "Writing" and "Oral Communication". Azerbaijan language and literature course has 4-5 hours in one week and Azerbaijan Language course is grouped as writing, reading, listening and speaking domains. Azerbaijani Turkish course was introduced to the $9-10^{\text {th }}$ grades for the first time in1993-1994 academic year curriculum. After the proclamation of independence it was advocated in the new Azerbaijani curriculum that Azerbaijani Turkish would be taught in all grades. In year 2003, a new material based on "Umumtahsil Mekteplerinin V-XI. sınıfları İçin Azerbaijan Dili Programı (Bakü-2002)" was designed to guide freshman teachers. The main objective of 2003- dated supplementary material was to execute Azerbaijani Turkish courses in accordance with the new school curriculum. Currently, in Azerbaijan schools, Azerbaijani Turkish is taught as stipulated by 2002 dated curriculum (Celilova, 2012, p. 201). As we analyze literature course it surfaces that "After 1932 literature was integrated to secondary school education curriculum in Azerbaijan as a new course and it has been effective since then" (Yakic1 et al., 2016, p. 471). In the high-schools of Azerbaijan Republic for $10^{\text {th }}-11^{\text {th }}$ grades literature curriculum has been devised in two variants "A" and " $\mathrm{B}$ ". " $\mathrm{A}$ " is the main variant which is more encompassing and this variant observes mandatory standards of the state. "B" variant, on the other hand, is the school- adapted version of the main education scheme. This variant may vary across different schools (Celilova, 2012, p. 264-276). In the former literature curriculum literature teaching in Azerbaijan was based on the literary-historic principle. The course was offered in the first three grades as the $9^{\text {th }}, 10$ th, 11 th. Nevertheless, in year-2003 literature curriculum, these topics were taught in the $10^{\text {th }}$ and $11^{\text {th }}$ grades. $10^{\text {th }}$-grade curriculum covers a period extending from the most ancient era till the literature of $20^{\text {th }}$ century. $20^{\text {th }}$ century Azerbaijani literature on the other hand is taught only in grade-11 ${ }^{\text {th }}$ curriculum (Celilova, 2012, p. 266-267). As seen there is a chronological approach observed. In Turkey on the other hand units in year-2018 Turkish Language and Literature curriculum are taught as genre-centered in the $9^{\text {th }}$ grade while in grades $10,11,12$ a cyclical approach has been observed.

\section{c. Language-Literature Textbooks in Turkey and Azerbaijan}

In the Dictionary of Educational Terminology (1974); course book is defined as a book prepared or selected in relation to teaching one particular lesson; it is the suggested book upon conducting analyses based on specific criteria as the main source for a particular school, grade and lesson for the use of teachers and students; thus being the most vital assistance for the teacher and students. Textbooks are designed in accordance with the curriculum. At educational institutes teaching of language and literature which can be realized via literary texts, textbook is one of the most essential teaching materials. Turkish and Azerbaijani Language-Literature textbooks constituting the scope of our research have been investigated with respect to the dimensions of visual design and context.

Table 2. Comparison of $10^{\text {th }}$ grade textbooks of Turkey and Azerbaijan with respect to visual design

\begin{tabular}{|c|c|c|}
\hline $\begin{array}{c}\text { Turkey's } \\
\text { Turkish Language and Literature }\end{array}$ & \multicolumn{2}{|c|}{$\begin{array}{c}\text { Azerbaijan's } \\
\text { Literature Azerbaijan Language }\end{array}$} \\
\hline Thin, colored carton cover & Thin, colored carton cover & Thin, colored carton cover \\
\hline 328 pages & 208 pages & 208 pages \\
\hline $\begin{array}{l}\text { White-color, tearable sheets. } \\
\text { The cover images the language } \\
\text { employed in context, traditional theatre, } \\
\text { public literature legends, dominant } \\
\text { yellow color for soul texts and } \\
\text { corresponding visuals being employed } \\
\text { on the book cover. }\end{array}$ & $\begin{array}{l}\text { White-color, tearable sheets. } \\
\text { A green-colored book cover } \\
\text { illustrated with sculptures and } \\
\text { Azerbaijan edifice. }\end{array}$ & $\begin{array}{l}\text { White-color, tearable sheets. } \\
\text { A colored book cover depicting the } \\
\text { statements on humans, Azerbaijan, } \\
\text { language, unity, idea, and civilization. }\end{array}$ \\
\hline $\begin{array}{l}\text { Diagram of Turkish language's } \\
\text { historical development, diagram of the } \\
\text { respective periods of Turkish literature. } \\
\text { On page } 313 \text { there is a map of Turkish } \\
\text { language and world map of Kaşgarlı } \\
\text { Mahmud. }\end{array}$ & No map displayed. & No map displayed. \\
\hline $\begin{array}{l}\text { Starting from page } 315 \text { towards the } \\
\text { final pages of book there are evaluation } \\
\text { and observation forms. On page } 320 \text {, } \\
\text { there is dictionary of literary } \\
\text { terminology and on page } 324 \\
\text { bibliography is listed. }\end{array}$ & $\begin{array}{l}\text { At the end of the book there is a } \\
\text { dictionary on the meaning of signs in } \\
\text { the book, dictionary of literary } \\
\text { terminology and essential works to } \\
\text { read on the particular periods } \\
\text { illustrated in the book. There is } \\
\text { bibliography and on the final cover } \\
\text { page the name list of authors, and } \\
\text { information such as place and date of } \\
\text { publication are presented. }\end{array}$ & $\begin{array}{l}\text { At the end of the book there is a } \\
\text { dictionary, full names of the people } \\
\text { whose names were abbreviated in the } \\
\text { book and a bibliography. On the final } \\
\text { cover page the name list of authors, } \\
\text { redactors and editors is presented. }\end{array}$ \\
\hline
\end{tabular}


c.1. Visual design: In Turkey $10^{\text {th }}$ grade Turkish Language and Literature textbook is thin and has a colored carton cover, the book has 328 white pages which are all tearable. After the cover, there is a list of information on the writers of the book, publication date and place. Next page presents the names of editors and visual design specialists. There are no details on the responsible names of curriculum development, measurement and evaluation, psychological guidance and counseling specialists. Later there is Turkish National Anthem, Ataturk's Address to the Turkish Youth and Ataturk portrait. After the table of contents, there is a title for introduction of the book and unit contents. Starting of page 311 there is diagram of Turkish language's historical development, diagram of the respective periods of Turkish literature. On page 313 there is a map of Turkish language and world map of Kaşgarlı Mahmud. Starting from page 315 towards the final pages of book there are evaluation and observation forms. On page 320, there is a dictionary of literary terminology and on page 324 bibliography is listed.

Azerbaijan $10^{\text {th }}$ grade Literature textbook is thin and has a colored carton cover, the book has 208 white pages which are all tearable. Inside is a photo of Haydar Aliyev, Azerbaijan national anthem. Title of contents is given after the contents page, next, an introductory diagram of the book and unit specifications have been displayed in graphs.

At the end of $10^{\text {th }}$ grade literature book, there is a dictionary on the meaning of signs in the book, dictionary of literary terminology and essential works to read on the particular periods. There is a bibliography and on the final cover page the name list of authors, and information such as place and date of publication are presented.

As seen in literature book, inside of the $10^{\text {th }}$ grade Azerbaijan Language book there is also a photo of Haydar Aliyev and script of Azerbaijan national anthem. Language textbook is thin and has a colored carton cover, the book has 208 white pages which are all tearable. After the table of contents there is an introduction for the book. Later a conceptual map photo is put and text analysis stages are illustrated below different headings. At the end of the book there is a dictionary, full names of the people whose names were abbreviated in the book and a bibliography. On the final cover page the name list of authors, redactors and editors is presented.

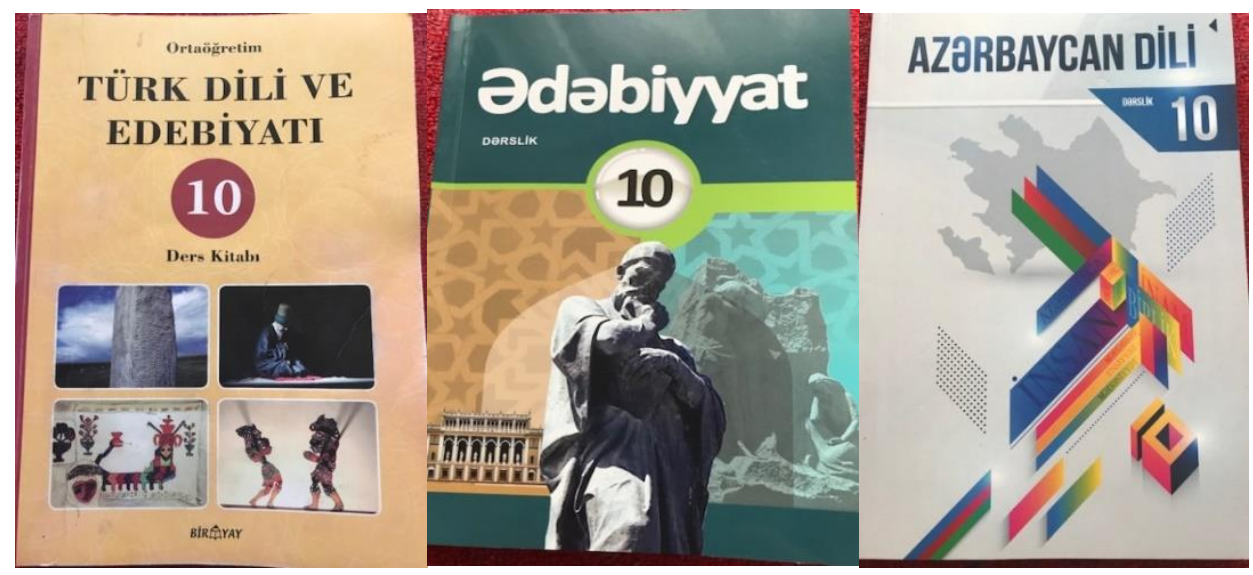

Figure $1.10^{\text {th }}$ grade textbook covers of Azerbaijan and Turkey

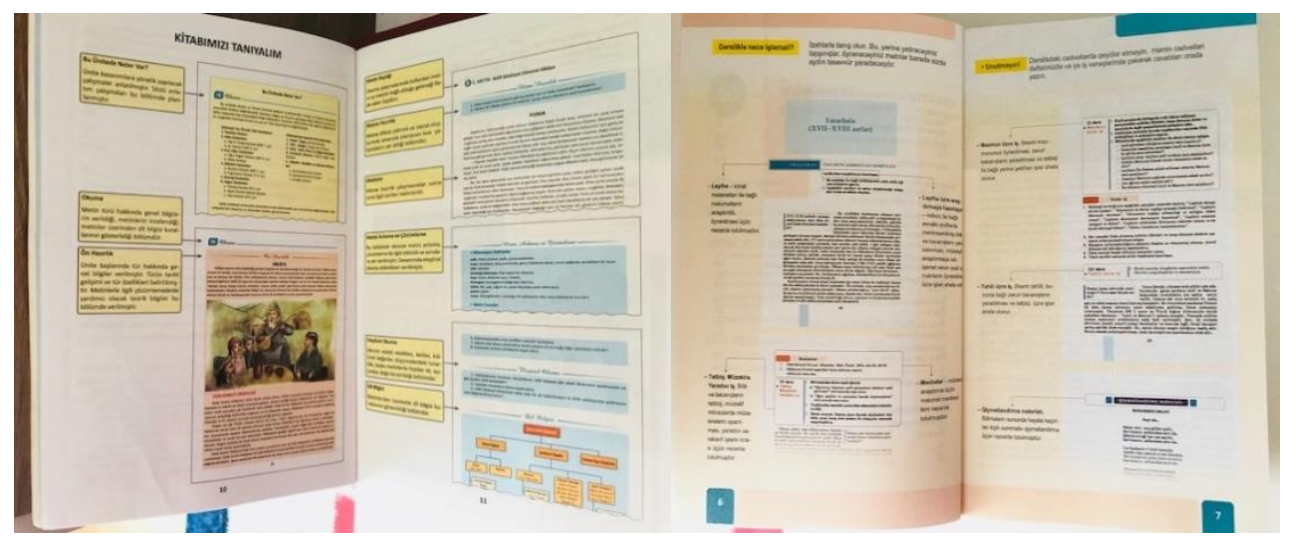

Figure 2. Book introduction diagram of the first pages of $10^{\text {th }}$ grade literature textbook in Azerbaijan

c.2. Context: In Turkey units of $10^{\text {th }}$-grade Turkish Language and Literature textbook generically consist of stages such as Preparation, Text: Unit, Duration and Contexts, Specific Word and Word Groups referred in the text, Explanations on 
the Text and Genre, Text Comprehension and Analysis, in-class activity, Author/poet Biography, Grammar, Writing: Writing activities, Recognition and Implementation of Text Genre and Techniques, Oral communication: Oral communication activities, Recognition and Implementation of Oral communication Genre and Techniques, Measurement and Evaluation Activities are integrated. There are 10 units in the $10^{\text {th }}$-grade textbook. Based on thematic approach these units are respectively classified as; $1^{\text {st }}$ Unit story, $2^{\text {nd }}$ Unit poetry, $3^{\text {rd }}$ Unit saga-legend, $4^{\text {th }}$ Unit petition-minutes, $5^{\text {th }}$ Unit novel, $6^{\text {th }}$ Unit theatre, $7^{\text {th }}$ Unit memoir, $8^{\text {th }}$ Unit news, $9^{\text {th }}$ Unit advertisement, $10^{\text {th }}$ Unit test. Based on unit classification the textbook is organized as genre-centered. Genre information and text analysis methods have been accentuated. In $10^{\text {th }}$ grade book there is a total of 53 texts. In Azerbaijan $10^{\text {th }}$ grade literature book, Azerbaijani literature has been examined on the basis of respective ages. Azerbaijani Oral Folk Literature has been treated as Antique Age Azerbaijani literature (till the XIII. century), Middle Age Azerbaijani Literature (works between XII-XVI centuries), and New Age Azerbaijani Literature (works between XVII-XVIII centuries). Data on respective ages and works have been provided; preparation, text analysis, research, forming small groups and discussion questions have also been demonstrated, and were utilized as assessment tools. In the beginning of the book there is a visual figure guiding the way to teach the course. Works and authors listed in the book are such: Dede Korkut Epic: Salur Kazan'ın Evinin Yağmalanması, Nizami Gencevî: İskendername, Nesimi: Sığmazam, Şah İsmail Hatai: Dehnâme, Fuzûlî: Beni Candan Usandırdı, Fuzûlî: Leylâ and Mecnun, Köroğlu Epic: Hamza'nın Kıratı Kaçırması, Molla PenahVagif: Peri, Kasım Bey Zakir :Bedi Saba Benim Derdi Dilimi, Mirza Feteliahundov: Aldanmış Kevakib, Aşık Alesger: Dağlar, Seyit Azim Şirvanî: Guşqil, Necef Bey Vezirov: Müsibet-i Fahrettin. There are a total of 13 texts. Context of Azerbaijan Language textbook for the $10^{\text {th }}$ grade shows that; book units are classified under 4 sections. In the $1^{\text {st }}$ section language and society, in the $2^{\text {nd }}$ section nature and us, in the $3^{\text {rd }}$ section family and society, in the $4^{\text {th }}$ section our national inheritance have been emphasized issues. Each section is devoted to 5-6 texts and in the introduction part of the book it is argued that each and every Azerbaijan citizen should know how to correctly, suitably and properly employ Azerbaijan language phonetics, structural features and the benefits of correct use of language. Each section covers listening \& comprehension and speaking, writing, grammar, preparation questions and visuals. Narrated works and authors in this book are listed such: Üzeyir Hacıbeyli: Language text, Afad Qurbanov: Cemi 40-Word text, Sabine Vahidqızi: It all started with water text, Beşeriyetin Yaddaşı text-Word text, Gülnar Maisqızı: I wanted to be a Journalist text, Samed Vurgun: Muğan, Füzuli Sabiroğlu: Şollar Su Kemeri text, The Caspian Sea text, Samed Vurgun: The plaint of the Plane tree text, Söhrab Tahir: Unity text, Oktay Zengilanlı: Martyrs poem, Tree of Love text, You rhetoric Me rhetoric text, Memmed Araz Menden Ötdü, Kardaşıma Değdi, Newspaper Texts on Hocalı Massacre, Praying Hands text, Abdürrahim Bey Hakverdiyev: Mirza Sefer, Haydar Aliyev: Examples from Azerbaijan State Constitution on the Conservation of Historical and Civilization Monuments, Gülnar Maisqız: There is someone from Vatican, Nicat İntiqam: Story of Imprisoned Tree, Rasim Efendi: Azerbaijani Pearls of Civilization in France, Möhbeddin Səmədin: Tunes of Spring, Mahbeddin Səmədin: On the Lightning Roads, National Clothes of Azerbaijan. There are a total of 23 texts.
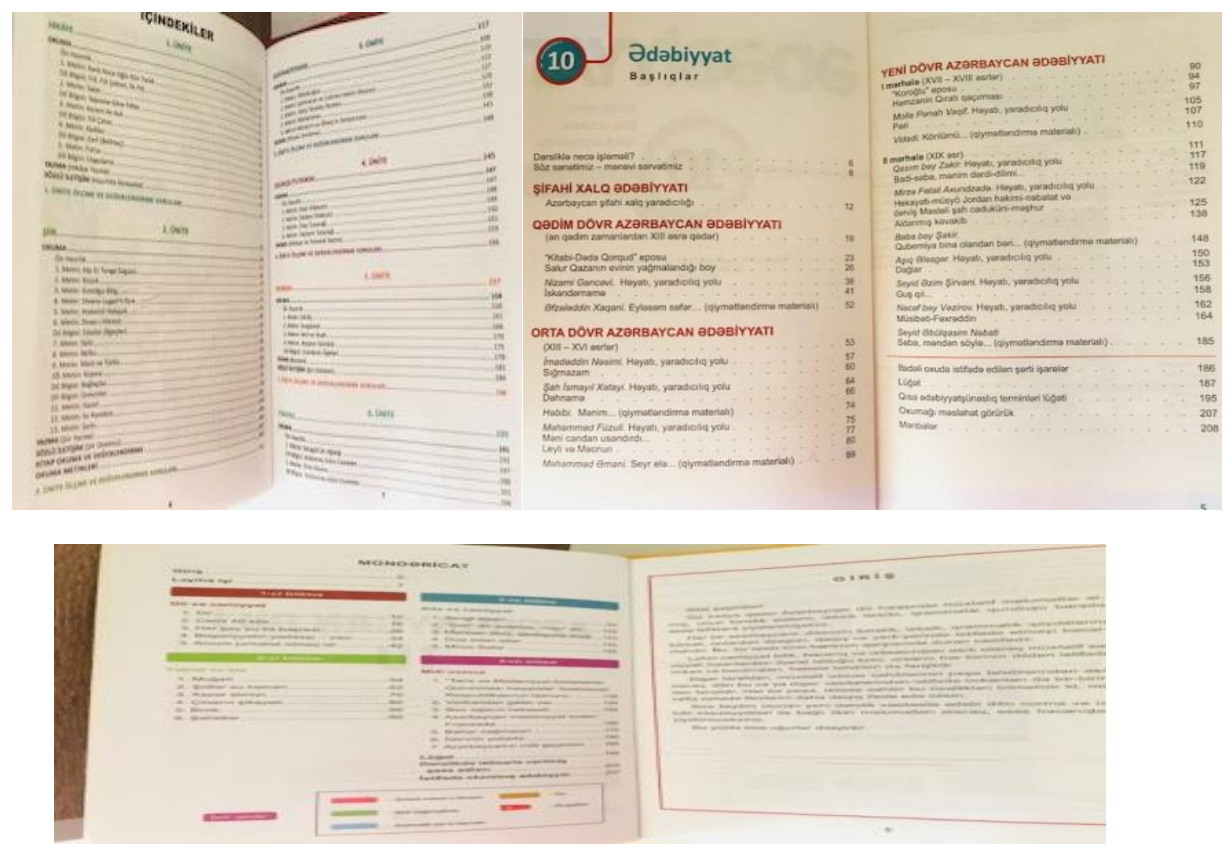

Figure 3. Table of contents of the $10^{\text {th }}$ grade literature and language books 
As emphasized in the new 2003-dated literature curriculum of Azerbaijan, from the previous curriculums not every item that has long been used and played an effective role in teaching of literature were totally discarded. As can be seen above; Nizami Gencevî, Nesimi, Fuzulî, Hatâi, Molla Penah Vagif, Mirza Fetheli Ahundov, Mirza Alekber Sabir, Celil Mehmetkuluzâde, Hüseyin Cavit, Cafer Cabbarl, Samet Vurgun and several other men of letters continued to be emphasized in the new curriculum as before: "No matter how often the curriculum changes these men of letters should never ever be left out in the new curriculums. However, in line with the shift of time, approach in teaching some of these writers' literary works could be moderated (Ümumtehsil Mekteblerinin V-XI. Sınıfları Üçün Edebiyyat Programı, 2003, p. 3-6; Celilova, 2003, p. 7 quot. Celilova, 2012, p. 265)."

Table 3. Comparison of $9^{\text {th }}, 10^{\text {th }}, 11^{\text {th }}$ grade textbooks of Turkey and Azerbaijan with respect to context

\begin{tabular}{l} 
Turkey \\
\hline On the basis of units textbook is organized as \\
genre-centered. \\
In text analysis: Specific Word and Word Groups referred in \\
the text, Explanations on the Text and Genre, Text \\
Comprehension and Analysis, in-class activity, Author/poet \\
Biography have been embedded.
\end{tabular}

In $9^{\text {th }}$-grade book, examples from world literature such as Guy de Maupassant, Çehov, Dostoyevski; Fuzûlî and Şeyhî from Turkish literature world have been presented.

In $10^{\text {th }}$-grade book some common literary examples of Turkish world such as Dede Korkut, Yunus Emre, Kerem İle Asl1, Alper Tunga Sagusu, Kutadgu Bilig, Divânu Lûgati't-Türk, Atabetü'l-Hakayı, Divan-1 Hikmet, Kaygusuz Abdal, Şeyhî, Karacaoğlan,Fuzûlî, Nedim, Şahmeran ve Lokman Hekim Efsanesi, Altay Yaratılış Destan1, Battalname have been presented. From world literature Lev Nikolayeviç Tolstoy's work Resurrection has been modeled.

In $10^{\text {th }}$ grade textbook there are 10 units, a total of 53 texts.

In $11^{\text {th }}$ grade book (literature +language) there is a total of 74 texts.

\section{Azerbaijan}

Textbook is organized in chronological approach. There is not a unit-based classification.

In text analysis: Before the text analysis sections such as "forming answers for the questions" and "preparation activities", text analysis, as for the text to be analyzed "questions on the text contents, discussion", "work analysis", research, forming small groups and discussion questions have been listed, there is a sample assessment tool under particular texts.

In $9^{\text {th }}$-grade book, an example from world literature namely Tolstoy; from Turkey and Turkish literary world Orhan Şaik Gökyay and Cengiz Aytmatov have been presented.

In $10^{\text {th }}$-grade book some common literary examples of Turkish world such as Kitab-i Dede Korkut Destan1, Nizami Gencevî, Nesimi, Şah İsmail Hatai, Fuzûlî and Köroğlu have been presented.

In $10^{\text {th }}$ grade textbook (literature +language) there is a total of $13+23$ texts.

In $11^{\text {th }}$ grade textbook (literature) there is a total of 12 texts.

\section{Results and Discussion}

Among the entire Turkish world after the proclamation of independence Azerbaijan established the fastest partnership with Turkish state among others. The most significant reason for this interaction was, as stated before, geographical proximity and mutual comprehensibility of oral language. Although educational relations between Turkey and Azerbaijan are not structured on quite solid grounds, this connection is still at top level when compared with the rest of Turkic Republics. The very first and legal ground between Azerbaijani and Turkish education relations was founded with respect to May $3^{\text {rd }}$-dated agreement titled as "Education, Teaching, Expertise Services, Technical and Scientific Partnership between Turkish Republic and Azerbaijan Republic". Ensuing the approval of this agreement by the parliaments of both countries respectively, it was witnessed that an accelerated process of cooperation took place. Nevertheless reasons for the low applicability of items in education partnership protocol and lack of sustainability for expansive student exchange projects should be attributed to the unsatisfying quality of education in both states (Büyükbaş, 2017, p. 16-19). Hence a number of initiatives have been implemented to remedy this failure. Indeed, conducted graduate studies as well as academic publications have long sought to find an answer to the question of the best format and context of textbooks and curriculums. To give a specific case, the focus of this study that analyzed curriculum and textbooks could be one of the bases to offer suggestions. Within that context it is suggested that for both states, instead of imitation and translation works, it is better to attain high-quality standards in international education by weaving education with national and cultural values; at the same time in order to determine the aspects of an ideal textbook both states are obliged to not only be well aware of their own culture, language and literature but also to monitor sample works from other nations and conduct a proper analysis in between. As an example, in Turkey and Azerbaijan, editorial staff and book sizes of textbooks are quite significantly lower compared to textbooks printed in Western states and the USA. For instance "In the USA a team of 83 -authors composing the editorial staff of the textbook and biography of the team members are provided in the beginning of the book" (Eskimen, 2015, p. 206). We also assume that in the USA thousands of book pages in textbooks are quite a salient indicators of the mighty size of books. "In teaching of language and literature the main motive is to develop students' reading pleasure and attitude towards books; thus instead of giving uncomplete or half complete literary works as model texts, the textbooks should 
give full texts as much as possible. Since it is not viable to provide full version of long texts such as novels, it would be more appropriate to include the sections on acquisitions. To the end of honing text-focused reading and developing critical thinking skills; implementation of pre-reading, while-reading and post-reading strategies is vitally critical" (Eskimen, 2015, p. 437). In the textbooks of Turkey and Azerbaijan, aside from developing reading skills, a range of activities were concocted to address to speaking, listening and writing skills. As for Turkey in the new $9^{\text {th }}$ and $10^{\text {th }}$ grade textbooks published after the merging of Turkish Language and Literature courses, there are guiding notes on oral communication and writing domains-unlike the previous textbook-but still these directories are far from being satisfactory and comprehensive. In Azerbaijan literature textbook for $10^{\text {th }}$ grade oral communication skills are usually performed with mechanical activities such as forming of small groups, getting together, debate and discussion which are very much identical with one another. In that sense new Azerbaijan Language (2017) textbook is more expansive when compared with previous issues. That is because in this issue, listening-speaking, writing, grammar questions and activities, language rules are displayed in parts displayed with different colors (see Figure 3); but that was not a common practice in the earlier versions; in this book questions are visually designed to fit into these categories. Yet in the books there is not any suggested method or technique to implement these skills. A better model is seen in the USA where before a writing activity, textbooks present extensive and explanatory information to the teachers by demonstrating a number of graphics and visual designs for effective writing strategies. Coordinated treatment of writing skills and technology, cooperative activities and peer assessment in writing have been emphasized points in western books. As a different example, in textbooks of France, there is a unit titled as "from writing to publishing". As stipulated in literature curriculum of the French course, the main objective is to help students understand that writing is not an act of creating out of nothing (Dervişcemaloğlu, 2007, p. 170). In England textbooks present a range of activities devoted to elevating reading \& comprehension and writing skills. In writing activities particularly it is vital that students can form their own style through practicing with creative, analytic and critical writing activities. Turkish Literature books heavily focus on text analysis, solution and interpretation (Çetin and Uzun, 2010, p. 410). In Turkey one of the most common criticisms directed to textbooks is that activities are extremely many and repetitive and questions are far away from creativity. Regarding the same matter a study that analyzed French language and literature textbook on high-school level highlighted that, "In French textbook there are not any excessive number of reading tasks and activities" (Dervişcemaloğlu, 2007, p. 157). The attitude adopted in the USA is nearly identical. "In USA textbooks, in lieu of teaching skills through activities; teachers opt for activities in which students can read the texts comprehensively and purposefully, respond to text-related questions, discuss (though it may be short) and write in detail to demonstrate the gist of the text and what they have learnt" (Eskimen, 2015, p. 298). In parallel with the shifts in globe and advancements in technology, scope of traditional-four skills has widened and started to entail domains of visual reading and presentation topics. Also classified as visual literacy, this domain was not treated individually in the Turkey-Azerbaijan high-school language and literature textbooks; still with the help of graphics, concept maps and images used in certain activities visual literacy was somehow emphasized. As a specific example Azerbaijan Language $10^{\text {th }}$ grade book unit-five is a particular model for imaging, visuality and interpretation. In addition to that regarding other multiple-literacy types such as media literacy and information literacy a number of revisions were implemented in the new Turkish Language and Literature Textbook.

As we delve into language-literature curriculum of both states, there were not any subject and unit-related objectives witnessed in year-2003 curriculum of Azerbaijan. In fact general objectives of a curriculum are essentials in determining the following contexts of units. In order for teachers to spot other salient items in units there is a need for unit-specific objectives too. Regarding this detection in his comparison between secondary-education geography course curriculums of Turkey (1992) and Azerbaijan (2003) Aladdinov (1996) argued that absence of units and unit objectives is one of the failures of the curriculum; it was also stated that aside from objectives in Azerbaijani language and literature curriculum, there were missing points in terms of teaching methods and material use. Regardingly Sadigov (2009) claimed that up until then recurrent attempts have been made in curriculum-development activities but geography teaching curriculums were not student-centered, disregarded technology use, failed to address problem-solving skills, were devoid of teaching methods and material use and thus forcing the students towards rote-learning. In addition to such adversities in Azerbaijani education system, after the enactment of 1992 Education Act "In education curriculums there was a surge in human elements and the number of education curriculums supportive of this change accelerated" (Akhundova, 2016, p. 13). It is safe to claim that such changes were particularly observable in the Azerbaijan Language $10^{\text {th }}$ grade textbook (2017). In that sense the book aimed to instill a range of values to found an awareness of language, environment, nature, family love, national, ethical and cultural consciousness and texts were selected to cater for these objectives

Located at the junction of different cultures and civilizations, Azerbaijan has been affected from these cultures and civilizations at varied levels and ways throughout its historical process (Turan, 2017, p. 600). In this process a number of revisions and amendments have been observed in teaching curriculums and textbooks. After 2003-dated curriculum, 
new books were published in years 2004 and 2009 in Azerbaijan. In 2017 some of the books were republished. This new publication for both literature and language books, as mentioned before, contained significant improvements compared to previous works. To illustrate; in the new Azerbaijan Language textbook (2017) there were activities and questions geared at reading, listening, writing, and speaking skills. Also in literature (2017) book students were expected to engage in activities and questions focusing on oral-communication skill. In this sense as regards use of technology students were expected to design a newspaper by using Microsoft publisher in Azerbaijan Language book. As noted it was aimed to move the textbooks away from traditional question-answer and lecturing methods, and to meet that objectives competency to employ oral-communication skills and harness the technology were foregrounded. In comparison to editions before year 2007, the books were prepared more diligently and appealing to the reader. The revision enabled the books to revive national literature, civilization and tradition on minds and also starting with objectives and acquisitions, the domains of visual design, visuality and context were rearranged to introduce a number of novelties. Furthermore it is detected that specific examples were taken from textbooks in Turkey and they were remodified accordingly. In relevant literature studies, Celilova (2012) states that in year-2009 publications to teach Azerbaijani Turkish and literature, new texts were to be selected and new methods away from rote learning but rather providing text-centered practices in cooperation with theoretical approaches should be opted for. It was also suggested that Azerbaijani Turkish and literature curriculum used in Azerbaijan should be revised on the basis of Turkish and literature curriculum as followed in Turkey.

In the $10^{\text {th }}$ and $11^{\text {th }}$ grade curriculums and textbooks of Azerbaijan a chronological approach was harnessed to examine the literary periods extending from anonymous-folk literature till the mids of $20^{\text {th }}$ century. Language analysis was treated separately in a different book as Azerbaijan Language. In language-text book for the $10^{\text {th }}$ grade more attention was paid to provide personal, moral and cultural values below the language title. Units were divided into sections such as language and society, nature and us, family and society, our national inheritance. In $11^{\text {th }}$ grade language book morphology, syntax and style units were dominant. In Azerbaijan textbooks there was not an informative section. In Turkey textbooks on the other hand the 2015-dated Education Act united Turkish literature, Language and Discourse courses below one heading as Turkish Language and Literature; it was organized on the basis of units and observed a cyclical approach. Grammar units were not treated in a separate curriculum or book but analyzed collectively within literature units. New textbooks that were prepared in line with the unified Turkish Language and Literature course provided novel insights. In Turkey there are in-class activities in textbooks but books in Azerbaijan listed a number of questions below the homework title (research).

In the textbooks of Turkey and Azerbaijan there are certain similarities with respect to sharing common literary works of Turkish world. For instance in Azerbaijan $10^{\text {th }}$ grade literature book common literary works of Turkish world Dede Korkut Epic, Nizami Gencevî, Nesimi, Şah İsmail Hatai, Fuzûlî and Köroğlu. $10^{\text {th }}$ grade textbook of Turkey also presented the works of Dede Korkut, Yunus Emre, Kerem İle Aslı, Alper Tunga Sagusu, Kutadgu Bilig, Divânu Lûgati't-Türk, Atabetü'l-Hakayık, Divan-1 Hikmet, Kaygusuz Abdal, Şeyhî, Karacaoğlan, Fuzûlî, Nedim, Şahmeran and Lokman Hekim Epic, Altay Yaratılıs Epic, Battalname. Indeed "Cultural riches of Turkish world, and in these works unchanged or slightly changed aspects in the face of ever-shifting life conditions" (Horata, 2003) are highlighted. These similarities are particularly evident in oral literature works as one of the products of language and literature. In that sense as also explained above both teaching curriculums of Turkey and Azerbaijan and particularly 2017-dated textbooks presented shared cultural riches ranging from mythology, saga, legend, tales and Dede Korkut stories. Celilova (2012) in his work titled as; "Teaching of language and literature in high-schools of Soviet-era and post-independence era Azerbaijan" concluded echoing results and stated that in teaching of Azerbaijani Turkish and literature it is suggested to refer more frequently to Turkey- Turkish texts primarily and common texts of Turkish world in general; he also recommended to spare wider place for common products of Folk Literature such as story, saga, legend, verse, lullaby, riddle and fables in published textbooks. It was noted that inclusion of shared products of Turkish nations in textbooks would allow Turkish nations to recognize one another more easily by manifesting their joint similarities shared across intangible cultural heritage.

By the same token, in the teaching curriculums of Turkey and Azerbaijan, a range of novel and poetry samples from world literature and Turkish community have been foregrounded. In relation to new textbooks to be prepared on the basis of 2018-dated Turkish Language and Literature curriculum it is expected to select poems from the Turkish world artists such as Bahtiyar Vahapzade and Şehriyar and students are then asked to devise and present a poetry recital consisting of Turkish world poetry. In the curriculum another point highlighted about Turkish world is on the quality of texts to be included in the textbooks. In the curriculum, the need to provide sample texts from the literature of Turkish world into the textbooks was particularly emphasized (p.16).

In line with the findings obtained from this research it is feasible to argue that when Azerbaijan and Turkish education systems are compared, one of the other similarities detected is that there is a centralized authority and responsibility in 
education system. Sadigov in his work (2009), "An analysis of employed secondary education level geography education and teaching curriculum in Azerbaijan and Turkey with respect to utilized methods and employed tools" argued that this practice could delay the provision of educational services to schools and in return there might be tardiness in notifying the center about emergent problems at schools and process of generating solutions when challenged with difficulties could be sluggish. Another similarity was observed in the reflection of national feelings in Azerbaijan Language-Literature curriculum and textbooks. In parallel with this argument Çalışkan (2016) in his work titled as "In Azerbaijan schools historical development of literature education and literature education curriculums" argued that in the selection of book-visual design the main objective of literature course taught in Azerbaijani schools was revival of Azerbaijan's national literature, civilization and traditions. This motive could be associated with the long-lasting attempts of the country to attain independence. In parallel with this argument Turan (2017), who conducted researches on Azerbaijan textbooks, stated that as a result of long-years of invasion to Azerbaijan lands and history-writing approach that dominated during the rule of USSR, one indispensable characteristics of Azerbaijan national identity has been rebellion and resistance against invasions, exploitations and injustices. Hence their textbooks provided larger segments to a good number of texts narrating revolts and insurgent movements. There is a strong emphasis attributed to national feelings in Azerbaijan curriculum and textbooks. In Turkish Language and Literature textbooks too there are signified values such as patriotism and a sense of responsibility; but in Azerbaijan literature, particularly in textbooks, there are additions to curriculums after independence and it was officially declared that the main objective of literature teaching was inoculation of national and moral values among learners and raise the students in a patriotic spirit while also teaching works that could present extolled intellectual ideas and a higher literary value. "In 2003-dated literature curriculum, not only Azerbaijani artists but also works from the Turkey-Turkish literature were also provided. Thus works that were intentionally excluded from curriculum in USSR-era on accounts of reflecting national feelings were annexed to the new curriculums after the proclamation of independence and it was declared that the main objective of literature teaching was inoculation of national and moral values among learners and raise the students in a patriotic spirit while also teaching works that could present extolled intellectual ideas and a higher literary value (Celilova, 2012, p. 291).

\section{References}

Agamaliyev, R. (1999). The educational system of the Republic of Azerbaijan. Milli Eğitim Dergisi, 144.

Akhundova, J. (2016). Socioeconomic transformation and the Education in Azerbaijan. Uluslararası Türk Kültür Coğrafyasinda Sosyal Bilimler Dergisi, 1 (1), 8-13.

Aladdinov, R. (2006). Turkey (1992) Azerbaijan (2003), comparison of secondary education school geography curriculums. Master thesis. Gazi University, Ankara, Turkey.

Büyükbaş, N. (2017). Azerbaycan Cumhuriyeti ile Türkiye Cumhuriyeti eğitim ilişkileri. Azerbaycan-Türkiye-25 yll. 1(17), 12-18 http://irs-az.com/new/files/2017/212/2668.pdf [Erişim Tarihi: 12.04.2018].

Celilova, V. (2012). Teaching language and literature in the Azerbaijan high schools during the Soviet Period and after the independence. Doctoral dissertation. Gazi University, Ankara, Turkey.

Çetin, İ., \& Uzun, Y. (2010). Teaching of literature in Turkey and United Kingdom (England). Gazi University Journal of Gazi Educational Faculty, 30(2), 397-412.

Dervişcemaloğlu, B. (2008). Methods of prose analysis in contemporary western education. Doctoral dissertation. Ege University, İzmir, Turkey.

Erden, M. (1998). Curriculum evaluation in education. Ankara: Anı Yayınc1lı.

Eskimen, A. D. (2015). Textbooks (Ed. İsmet Çetin). Language and literature teaching methods. Ankara: Nobel Yayıncillk, 433-467.

Gömeç, S. (2001). Azerbaycan Türk Cumhuriyeti. Türk Dünyası El Kitabı Birinci Cilt. 711-741, Coğrafya-Tarih. Ankara: Türk Kültürünü Araştırma Enstitüsü.

Horata, O. (2003). Türk dünyasının kültürel ufukları: Türk dünyası ortak edebiyatı. bilig, Türk Dünyası Sosyal Bilimler Dergisi, 25, 207-211.

İbrahimova, S. (2002). Compare of the social studies programs both in Turkey and Azebaijan. Master thesis, Marmara University, İstanbul, Turkey.

Mammadov, J. (2008). Changes and developments in Azerbaijanian educational system in the post independence period. Master Thesis. İstanbul University, İstanbul, Turkey.

Ministry of National Education (2018). Secondary education Turkish language and literature course $\left(9,10,11\right.$ and $12^{\text {th }}$ 
grade) curriculum. http://mufredat.meb.gov.tr/ProgramDetay.aspx?PID=353 [Erişim Tarihi 30.02.2018]

Oğuzkan, F. (1974). Dictionary of educational terminology. Ankara: Türk Dil Kurumu Yayınları.

Sadigov, İ. (2009). A comparative evaluation of secondary geography education in Azerbaijan and Turkey in terms of curricula, methodologies and equipment. Doctoral dissertation. Marmara University, İstanbul, Turkey.

Topal, E., \& Sezer, A. (2016). The Investigation of university students' awareness levels about geography of Turkish world. Marmara Coğrafya Dergisi, 33, 96-113. https://doi.org/10.14781/mcd.08328

Turan, R. (2017). Representation of Azerbaijan national identity in the textbook of fatherland used in Azerbaijan. SUTAD, Selçuk Üniversitesi Türkiyat Araştırmaları Dergisi, 42, 593-612.

Yakıcı, A., \& Savaşkan, V. (2016). Historical development of literature education and literature education programmes in Azerbaijan schools. A. Ü. Türkiyat Araştırmaları Enstitüsü Dergisi [TAED], 55, 469-483.

Yıldırım, A., \& Şimşek, H. (2008). Sosyal bilimlerde nitel araştırma yöntemleri. Ankara: Seçkin Yayıncılık.

Y1ld1z, E. (2007). A comparison between German and Turkish language and literature course books covered in first classes of high schools in Germany and Turkey. Master thesis, Gazi University, Ankara, Turkey.

\section{The examined textbooks:}

Aylin Hidayet Başaran Yılmaz (2017). Ortaöğretim Türk Dili ve Edebiyatı 10. Ankara: Bir-Yay Yayınevi.

Bilal Həsənli, Nəcəf Nəcəfov (2009). ədebiyyat 9. Xəzər, Bak1.

İfakat Yücel, Mahmut Türkyılmaz, Selim Sağır (2017). Ortaöğretim Türk Dili ve Edebiyatı 9. Ankara: Millî Eğitim Bakanlığı Yayınları.

Nizami Cəfərov, İsa Həbibbəyli, Nurlana əliyeva, Afət Bakıxanova (2014). ədebiyyat 11. Çaşığlu, Bakı.

Nizami Cəfərov, Teymur Kərimli, Zaman əsgərli, Afət Bakıxanova (2009). ədebiyyat 10. Çaşığlu, Bakı.

Soltan əliyev, Bilal Həsənov, Aynur Mustafayeva (2017). ədebiyyat 10. Bakı Neşr.

Tofiq Hacıyev, Nizami Cəfərov, Nizami Xudiyev (2014). Azerbaycan Dili 11. Bakı.

Tofiq Hacıyev, Samirə Bektaşi, Yeganə Hüseynova (2017). Azerbaycan Dili 10. Bakı.

\section{Copyrights}

Copyright for this article is retained by the author(s), with first publication rights granted to the journal.

This is an open-access article distributed under the terms and conditions of the Creative Commons Attribution license which permits unrestricted use, distribution, and reproduction in any medium, provided the original work is properly cited. 